\title{
Risk of Getting COVID-19 in People With Multiple Sclerosis
}

\author{
A Case-Control Study
}

Pietro laffaldano, MD, Giuseppe Lucisano, MSc Stat, Alessia Manni, MD, Damiano Paolicelli, MD, Francesco Patti, MD, Marco Capobianco, MD, Vincenzo Brescia Morra, MD, Patrizia Sola, MD, llaria Pesci, MD, Giacomo Lus, MD, Giovanna De Luca, MD, Alessandra Lugaresi, MD, Paola Cavalla, MD, Sara Montepietra, MD, Giorgia Teresa Maniscalco, MD, Franco Granella, MD, Paolo Ragonese, MD, Marika Vianello, MD, Laura Brambilla, MD, Rocco Totaro, MD, Simona Toscano, MD, Simona Malucchi, MD, Maria Petracca, MD, Lucia Moiola, MD, Diana Ferraro, MD, Vito Lepore, MD, Paola Mosconi, Biol Sci D, Michela Ponzio, PhD, Gioacchino Tedeschi, MD, Giancarlo Comi, MD, Mario Alberto Battaglia, MD, Massimo Filippi, MD, Maria Pia Amato, MD, and Maria Trojano, MD, on behalf of the Italian MS Register

Neurol Neuroimmunol Neuroinflamm 2022;9:e1141. doi:10.1212/NXI.0000000000001141

\section{Abstract}

\section{Background and Objectives}

Several studies have assessed risk factors associated with the severity of COVID-19 outcomes in people with multiple sclerosis (PwMS). The potential role of disease-modifying therapies (DMTs) and demographic and clinical factors on the risk of acquiring SARS-CoV-2 infection has not been evaluated so far. The objective of this study was to assess risk factors of contracting SARS-CoV-2 infection in PwMS by using data collected in the Italian MS Register (IMSR).

\section{Methods}

A case-control (1:2) study was set up. Cases included PwMS with a confirmed diagnosis of COVID-19, and controls included PwMS without a confirmed diagnosis of COVID-19. Both groups were propensity score-matched by the date of COVID-19 diagnosis, the date of last visit, and the region of residence. No healthy controls were included in this study. COVID-19 risk was estimated by multivariable logistic regression models including demographic and clinical covariates. The impact of DMTs was assessed in 3 independent logistic regression models including one of the following covariates: last administered DMT, previous DMT sequences, or the place where the last treatment was administered.

Correspondence Prof. Trojano maria.trojano@uniba.it
MORE ONLINE

III Class of Evidence

Criteria for rating

therapeutic and diagnostic studies

NPub.org/coe

MORE ONLINE

COVID-19 Resources

For the latest articles, invited commentaries, and blogs from physicians around the world NPub.org/COVID19

\section{Results}

A total of 779 PwMS with confirmed COVID-19 (cases) were matched to 1,558 PwMS without COVID-19 (controls). In all 3 models, comorbidities, female sex, and a younger age were significantly associated $(p<0.02)$ with a higher risk of contracting COVID-19. Patients receiving natalizumab as last $\operatorname{DMT}(\mathrm{OR}[95 \% \mathrm{CI}]: 2.38[1.66-3.42], p<0.0001)$ and those who underwent an escalation treatment

\footnotetext{
From the Department of Basic Medical Sciences (P.I., G.L., A.M., D.P., M.T.), Neurosciences and Sense Organs, University of Bari Aldo Moro; CORESEARCH (G.L.), Pescara; Dipartimento di Scienze Mediche e Chirurgiche e Tecnologie Avanzate (F.P., S.T.), GF Ingrassia, Sez. Neuroscienze, Centro Sclerosi Multipla, Università di Catania; SCDO Neurologia e Centro di Riferimento Regionale Sclerosi Multipla (CRESM) (M.C., S.M.), AOU San Luigi-Orbassano (TO); Department of Neurosciences (V.B.M., M.P.), Reproductive and Odontostomatological Sciences, 'Federico II' University of Naples; Centro malattie Demielinizzanti (P.S.), Azienda Ospedaliera Universitaria di Modena/OCB, UO Neurologia; Centro SM UO Neurologia, Ospedale Di Vaio (I.P.), Fidenza, AUSL PR; Multiple Sclerosis Center (G. Lus), II Division of Neurology, Department of Clinical and Experimental Medicine, Second University of Naples; Centro Sclerosi Multipla (G.D.L.), Clinica Neurologica, Policlinico SS. Annunziata, Chieti; IRCCS Istituto delle Scienze Neurologiche di Bologna (A.L.), UOSI Riabilitazione Sclerosi Multipla, Bologna; Dipartimento di Scienze Biomediche e Neuromotorie (A.L.), Università di Bologna; Centro SM (P.C.)—Neurologia 1 D.U.-AOU Citta' Della Salute E Della Scienza Di Torino; Centro SM (S.M.), S.O.C. Neurologia, Arcispedale Santa Maria Nuova, AUSL-IRCCS Reggio Emilia; Neurological Clinic and Multiple Sclerosis Center (G.T.M.), A Cardarelli Hospital, Naples; Centro Sclerosi Multipla (F.G.), Azienda Ospedaliero-Universitaria di Parma; Department of Biomedicine (P.R.), Neuroscience and Advanced Diagnostics, University of Palermo; Centro Sclerosi Multipla UO Neurologia-Ospedale (M.V.), Treviso; Fondazione IRCCS Istituto Neurologico "C. Besta" U.O. Neuroimmunologia e Malattie Neuromuscolari (L.B.); Centro Malattie Demielinizzanti (R.T.), Clinica Neurologica, Ospedale San Salvatore-L'Aquila; Dipartimento di Neurologia (L.M., M.F.), Neurofisiologia e Neuroriabilitazione, San Raffaele Scientific Institute, Vita-Salute San Raffaele University, Milan; Department of Biomedical (D.F.), Metabolic and Neurosciences, University of Modena and Reggio Emilia; Istituto di Ricerche Farmacologiche Mario Negri IRCCS (V.L., P.M.), Milano, Italy; Scientific Research Area (M.P.), Italian Multiple Sclerosis Foundation, Genoa; First Division of Neurology (G.T.), Department of Advanced Medical and Surgical Sciences, MRI Research Center SUN-FISM, AOU, University of Campania "Luigi Vanvitelli," Naples; Institute of Experimental Neurology (G.C.), IRCCS San Raffaele Hospital, Milan; Department of Life Sciences (M.A.B.), University of Siena; Department NEUROFARBA (M.P.A.), University of Florence; and IRCCS Fondazione Don Carlo Gnocchi (M.P.A.), Florence, Italy.
}

Go to Neurology.org/NN for full disclosures. Funding information is provided the end of the article.

Italian MS Register coinvestigators are listed in Appendix 2.

The Article Processing Charge was funded by the authors.

This is an open access article distributed under the terms of the Creative Commons Attribution-NonCommercial-NoDerivatives License 4.0 (CC BY-NC-ND), which permits downloading and sharing the work provided it is properly cited. The work cannot be changed in any way or used commercially without permission from the journal. 


\section{Glossary}

DMT = disease-modifying therapy; EC = ethical committee; EDSS = Expanded Disability Status Scale; IMSR = Italian MS Register; IQR = interquartile range; MedDRA = Medical Dictionary for Regulatory Activities; MoA = mechanisms of action; MS = multiple sclerosis; PS = propensity score; PwMS = people with multiple sclerosis.

strategy (1.57 [1.16-2.13], $p=0.003)$ were at significantly higher COVID-19 risk. Moreover, PwMS receiving their last DMT requiring hospital access $(1.65$ [1.34-2.04], $p<0.0001)$ showed a significant higher risk than those taking self-administered DMTs at home.

\section{Discussion}

This case-control study embedded in the IMSR showed that PwMS at higher COVID-19 risk are younger, more frequently female individuals, and with comorbidities. Long-lasting escalation approach and last therapies that expose patients to the hospital environment seem to significantly increase the risk of SARS-CoV2 infection in PwMS.

\section{Classification of Evidence}

This study provides Class III evidence that among patients with MS, younger age, being female individuals, having more comorbidities, receiving natalizumab, undergoing an escalating treatment strategy, or receiving treatment at a hospital were associated with being infected with COVID-19. Among patients with MS who were infected with COVID-19, a severe course was associated with increasing age and having a progressive form of MS, whereas not being on treatment or receiving an interferon beta agent was protective.

In 2019, a new coronavirus-the SARS-CoV-2 responsible for COVID-19-appeared and quickly became pandemic. ${ }^{1}$ As the number of COVID-19 cases increased over time, many questions have arisen about the risk of COVID-19 for individuals with autoimmune disease and the management of patients who need immunotherapies. ${ }^{2}$ Up to $70 \%$ of people with multiple sclerosis (PwMS) are treated with disease-modifying therapies (DMTs) that affect the immune response; in turn, these therapeutic agents may expose the patient to increased risk of developing COVID19 and experiencing worse COVID-19 outcomes $^{3}$ than individuals not receiving these agents. Several national and international initiatives have been set up to rapidly collect data about potential risk factors associated with the severity of COVID-19 in PwMS. ${ }^{4}$

${ }^{6}$ Most studies have consistently demonstrated male sex, an older age, the presence of comorbidities, and higher disability as risk factors for a more severe disease course. ${ }^{4-9}$ The potential critical role of MS immunotherapies in the COVID-19 severity has also been investigated with conflicting results. Several studies showed an increased risk of a severe course for PwMS with a recent use of methylprednisolone ${ }^{4-7}$ and a last therapy with depletive antiCD20 drugs ${ }^{4,6,7}$; others did not find any association between DMT exposure and COVID-19 severity, ${ }^{5,8,9}$ whereas some researchers reported a protective role of interferon beta agents. ${ }^{4,5,7}$

Therefore, recommendations have emerged regarding the management of DMT exposure based on respective mechanisms of action (MoA). ${ }^{10}$ However, such an approach must be carefully evaluated to balance the temptation to stop or delay specific DMTs to reduce the risk of severe COVID-19 outcomes and the potential impact on MS reactivation and disability progression that such a treatment choice could imply. ${ }^{11,12}$ Choice of treatment strategy, in general and particularly during the COVID-19 pandemic, should take into account differences in MoA and duration of the immunologic effects of each therapy, which can vary and may be shortlasting or persist for some years. ${ }^{13}$ The cumulative effect of DMT sequencing on the immune system must also be carefully evaluated. ${ }^{14}$

So far, factors increasing the risk of acquiring SARS-CoV-2 infection in PwMS have not been evaluated. MS registers, however, offer a unique tool for the provision of denominators for answering this question and afford the possibility of analyzing data regarding the complete MS history in patients with and without SARS-CoV-2 infection, including information on DMT exposure duration and treatment sequencing.

In this article, using data collected from the Italian MS Register (IMSR), we conducted, for the first time, a case-control study aimed at investigating factors associated with the risk of getting COVID-19. We focused not only on the role of the last administered therapy but also on the potential cumulative effect of previous DMT sequences and on the location where the last treatment was administered (i.e., hospital-based or home-based treatment). As a secondary objective, we further assessed the risk factors associated with the severity of COVID-19 outcomes.

\section{Methods}

\section{Standard Protocol Approvals, Registrations, and Patient Consents}

This study was conducted using longitudinal, prospectively acquired clinical data extracted from the IMSR ${ }^{15}$ The IMSR 
was approved by the ethical committee (EC) of the Azienda Ospedaliero-Universitaria - Policlinico of Bari (Study REGISTRO SM001, approved on August 7, 2016) and the local EC of all participating centers. All patients signed informed consent allowing the use of demographical and clinical data for research purposes.

\section{Data Extraction}

In 2020, health-care professionals who contributed data to the IMSR were asked to report all MS cases with laboratory confirmed (i.e., using PCR or serology test) diagnosis of COVID-19 using the adverse event module of the IMSR webbased data collection tool. This module enables the collection of the following information: COVID-19 diagnosis according to the Medical Dictionary for Regulatory Activities (MedDRA), ${ }^{16}$ date of event, severity of the infection (mild, moderate, severe, or critical), and date of resolution (with or without sequelae) or date of death. To prevent patients with suspected COVID-19 from being included among the controls, we excluded the patients for whom the adverse event module included a MedDRA code for suspected COVID-19 without a confirmation of the diagnosis by PCR or a positive result for serologic anti-SARS-CoV2 test from the data set.

The decision regarding what level of COVID-19 severity to assign was left to the neurologist's judgment. Patients who had an asymptomatic course or only mild general symptoms were classified as mild; patients who presented with more prominent general symptoms, with possible need for oxygen supplementation, but who did not require hospitalization were defined as moderate; and finally, patients who required hospitalization and/or who eventually died of Covid-19 were defined as severe/critical cases. By the end of December 2020, when anti-COVID-19 vaccines were made available in Italy, the collection of information regarding vaccination status (date, type, and number of doses) was also collected in the IMSR.

Comorbidities, codified according to International Classification of Diseases- 9 codes, were extracted from the data set of the IMSR. Comorbidities included the following: allergy, autoimmune diseases, cardiovascular diseases, epilepsy, headache, tumors, psychiatric disorders, thyroid dysfunctions, and others.

In Italy, all IV immunotherapies are administered at hospital infusion centers in accredited MS centers.

\section{Study Design}

To evaluate the demographic and clinical factors associated with the risk of COVID-19 in PwMS, a case-control study (1:2) was established. Cases were defined as PwMS with confirmed COVID-19, as reported in the adverse event module of the IMSR web-based application. Controls were selected from the IMSR data set from PwMS without a diagnosis of COVID-19 using propensity score (PS) matching based on the date of the last visit and locality. Patients who received the anti-COVID-19 vaccination and who had not experienced COVID-19 infection before vaccination were excluded from the analysis, thus avoiding the possibility of being selected as controls.

\section{Statistical Analysis}

Between-group comparisons were performed by using the Student test, Mann-Whitney test, Kruskal-Wallis test, or $\chi^{2}$ test, as appropriate. Controls were identified using a logistic regression model including COVID-19 diagnosis date/date of last visit and region of residence as covariates to predict the probability (PS) of developing COVID-19. An 8-to-1 greedy matching algorithm was used to identify 2 matched controls for each positive case according to the PS. Adequacy of balance for the covariates in the matched sample was assessed using standardized mean difference between the 2 groups, considering differences of less than $10 \%$ as good balance, and graphical methods. ${ }^{17-19}$

Multivariable logistic regression models were used to assess the association between risk factors and COVID-19 occurrence. The following covariates were included in the models: sex (male vs female individuals), age, disease duration $(\leq 10$, $11-20,>20$ years), course of disease (progressive vs relapsing), presence of one or more of the following comorbidities: allergy, autoimmune diseases, cardiovascular diseases, epilepsy, headache, tumors, psychiatric disorders, thyroid dysfunctions and others (yes/no), Expanded Disability Status Scale (EDSS) score at the last visit, and relapses in the previous year (yes/no). The impact of DMT exposure was assessed in 3 independent logistic regression models in which one of the following, mutually exclusive, covariates was added: (1) last administered DMT, (2) type of previous DMT sequences administered from disease onset (only moderate efficacy DMT, only high efficacy DMT, and moderate efficacy DMT, followed by high efficacy DMT) or (3) the place where the last treatment was administered (hospital-based or home-based treatment).

Specifically, high efficacy DMT included natalizumab, fingolimod, cyclophosphamide, mitoxantrone, cladribine, alemtuzumab, methotrexate, rituximab, and/or ocrelizumab; moderate efficacy DMTs included interferon beta products, glatiramer acetate, teriflunomide, dimethyl fumarate, and/or azathioprine; treatments administered at hospital included natalizumab, cyclophosphamide, mitoxantrone, alemtuzumab, rituximab, or ocrelizumab; treatments self-administered at home included fingolimod, cladribine, methotrexate, interferon beta products, glatiramer acetate, teriflunomide, dimethyl fumarate, or azathioprine.

To ensure that results were sufficiently robust, only treatments that were started at least 30 days before COVID-19 diagnosis were included to account for intermittently dosed DMTs and to prevent assigning risk to a DMT started only a few days before COVID-19 diagnosis. For the secondary objective of our study, which was the identification of risk factors associated with a severe course of COVID-19, a Poisson regression model with correction for overdispersion 
was built using the same covariates included in the casecontrol analysis. A 2 -sided $p$ value of $<0.05$ was deemed significant. Statistical analyses were performed with SAS software, version 9.4 (SAS Institute, Cary, NC) and R, version 3.2.0.

\section{Data Availability}

The data analyzed in this study are the property of the individual contributing centers. They can be made available on reasonable request for the purpose of replication of the analyses included in this study and at the discretion of the principal investigators.

\section{Results}

\section{Risk Factors for Acquiring COVID-19 in PwMS}

As of March 31, 2021, data from 779 PwMS with confirmed COVID-19 (96.3\% confirmed by PCR, 3.7\% confirmed by a serologic anti-SARS-CoV2 test) and 1,558 PS-matched controls were extracted from the IMSR.

The demographic and disease characteristics of cases and controls are reported in Table 1. Cases were younger (median [IQR] age: $42.40[33.00-50.80]$ vs 46.90 [37.50-55.70] years, $p<0.0001$ ), less disabled (median [interquartile range (IQR)] EDSS: 2.00 [1.00-3.50] vs 2.00 [1.00-4.50], $p=$ $0.0006)$, more frequently female individuals $(69.83 \%$ vs $64.18 \% p=0.0066)$, with comorbidities ( $8.22 \%$ vs $5.26 \%, p=$ $0.0054)$, with a disease duration $\leq 10$ years $(44.16 \%$ vs $38.83 \%$, $p=0.0054)$, with a relapsing disease course $(86.26 \%$ vs $78.95 \%, p<0.0001)$, and with at least 1 relapse in the last year $(12.20 \%$ vs $8.28 \%, p=0.0024)$ in comparison with controls.

Regarding DMT exposure, cases were less frequently treated with interferon beta products $(13.35 \%$ vs $19.26 \%, p<0.0001)$, with DMT being self-administered at home $(55.71 \%$ vs $63.41 \%, p<0.0001$ ) and more frequently treated during the course of the disease with only high efficacy DMT or moderate efficacy DMTs followed by high efficacy DMT strategies (18.23\% vs $15.60 \%, 30.17 \%$ vs $23.11 \%, p<0.0001$, respectively) in comparison with controls (Figure).

In all the 3 primary logistic regression models (Tables 2-4), the presence of comorbidities (ranging between 69\% and $74 \%$ of increased risk) and female sex (ranging between $25 \%$ and $27 \%$ of increased risk) were found to be significantly and consistently associated with a higher risk of acquiring COVID-19, whereas age was associated with a lower risk of acquiring COVID-19 (each year of current age was associated with a decreased risk ranging from $10 \%$ to $11 \%$ ).

Regarding the impact of DMTs, we found, in the first model (Table 2), based on the last DMT, a significantly higher risk of COVID-19 infection in patients who received natalizumab (OR [95\% CI]: 2.38 [1.66-3.42]). In the second model (Table 3), based on the evaluation of treatment strategies received during the whole disease course, patients who underwent an escalation strategy from moderate efficacy DMTs followed by high efficacy DMTs were at significantly higher risk of getting COVID-19 (1.57 [1.16-2.13]) in comparison with patients never treated and those exposed only to first-line DMTs. Finally, in the third model (Table 4), which considered the place of treatment administration of the last DMT, a significantly higher risk of getting COVID-19 was found in patients who received treatment at the hospital and needed more frequent access to the MS center (1.65 [1.34-2.04]) in comparison with those who took self-administered DMT at home.

\section{Risk Factors for Developing Severe COVID-19 in PwMS}

Among the 779 PwMS with a confirmed diagnosis of COVID$19,643(82.5 \%)$ were reported as affected by a mild, 116 (14.9\%) by a moderate, and only $20(2.6 \%)$ by a severe disease course. Five patients died ( 4 men; mean age: 60.6 years; mean disease duration: 14 years; mean EDSS: 4.8), 3 experienced a relapsing course, and 2 experienced a progressive course. Each of them received a different last DMT (glatiramer acetate, ocrelizumab, azathioprine, natalizumab, and fingolimod).

The main clinical and demographic characteristics of PwMS with COVID-19 are summarized in Table 5. PwMS exhibiting a severe COVID-19 course were significantly older $(p<$ $0.0001)$, more frequently male individuals $(p=0.04)$, more disabled $(p=0.0003)$, and more frequently with a progressive form $(p<0.0001)$ in comparison with those affected by a mild or moderate COVID-19 disease course.

The multivariable Poisson regression model showed that older age $(p=0.0004)$ and a progressive disease course $(p=$ 0.0067 ) were the most significant risk factors of a severe COVID-19 course, whereas being treated with interferon beta products $(p=0.0476)$ and not treated at all $(p=0.0356)$ were associated with a lower risk (Table 6).

\section{Classification of Evidence}

This study provides Class III evidence that among patients with MS, younger age, being female, having more comorbidities, receiving natalizumab, undergoing an escalating treatment strategy, or receiving treatment at a hospital was associated with being infected with COVID. Among patients with MS who were infected with COVID-19, a severe course was associated with increasing age and experiencing a progressive form of MS, whereas not being on treatment or receiving an interferon beta agent was protective.

\section{Discussion}

Unlike most articles published so far during the COVID-19 pandemic, ${ }^{4-9,20}$ which focus on the identification of factors associated with the severity of COVID-19 outcomes in 
Table 1 Demographic and Clinical Characteristics of PwMS With COVID-19 (Cases) and PwMS Without COVID-19 (Controls)

\begin{tabular}{|c|c|c|c|}
\hline Variable & $\begin{array}{l}\text { PwMS with COVID-19 } \\
(\mathrm{n}=779)\end{array}$ & $\begin{array}{l}\text { PwMS without COVID-19 } \\
(n=1,558)\end{array}$ & $p$ Value \\
\hline Age, median (IQR), y & $42.40(33.00-50.80)$ & $46.90(37.50-55.70)$ & $<0.0001$ \\
\hline Patients with comorbidities, $\mathbf{n}(\%)$ & $64(8.22)$ & $82(5.26)$ & 0.0054 \\
\hline \multicolumn{4}{|l|}{ Disease duration, classes } \\
\hline$\leq 10$ & $344(44.16)$ & $605(38.83)$ & 0.0054 \\
\hline $11-20$ & $272(34.92)$ & $525(33.70)$ & \\
\hline$>20$ & $147(18.87)$ & $388(24.90)$ & \\
\hline Missing & $16(2.05)$ & $40(2.57)$ & \\
\hline Female sex, n (\%) & $544(69.83)$ & $1,000(64.18)$ & 0.0066 \\
\hline EDSS score, median (IQR) & $2.00(1.00-3.50)$ & $2.00(1.00-4.50)$ & 0.0006 \\
\hline Number of EDSS scores, median (IQR) & $10.00(5.00-20.00)$ & $10.00(5.00-20.00)$ & 0.8316 \\
\hline Patients with at least 1 relapse in the previous year, $n(\%)$ & $95(12.20)$ & $129(8.28)$ & 0.0024 \\
\hline \multicolumn{4}{|l|}{ Disease course } \\
\hline Relapsing & $672(86.26)$ & $1,230(78.95)$ & $<0.0001$ \\
\hline Progressive & $78(10.01)$ & $260(16.69)$ & \\
\hline Missing & $29(3.72)$ & $68(4.36)$ & \\
\hline \multicolumn{4}{|l|}{ Last DMT recorded, n (\%) } \\
\hline Alemtuzumab & $16(2.05)$ & $24(1.54)$ & $<0.0001$ \\
\hline Teriflunomide & $33(4.24)$ & $87(5.58)$ & \\
\hline Azatioprine & $15(1.93)$ & $34(2.18)$ & \\
\hline Dimethyl fumarate & 117 (15.02) & $197(12.64)$ & \\
\hline Glatiramer acetate & $56(7.19)$ & 165 (10.59) & \\
\hline Cyclophosphamide & $4(0.51)$ & $9(0.58)$ & \\
\hline Fingolimod & $83(10.65)$ & $164(10.53)$ & \\
\hline Methotrexate & $5(0.64)$ & $16(1.03)$ & \\
\hline Natalizumab & 137 (17.59) & $120(7.70)$ & \\
\hline Mitoxantrone & $3(0.39)$ & $12(0.77)$ & \\
\hline Interferon beta products & 104 (13.35) & $300(19.26)$ & \\
\hline Rituximab & $18(2.31)$ & $36(2.31)$ & \\
\hline Ocrelizumab & 70 (8.99) & $131(8.41)$ & \\
\hline Cladribine & $21(2.70)$ & $25(1.60)$ & \\
\hline Never treated & $97(12.45)$ & $238(15.28)$ & \\
\hline \multicolumn{4}{|c|}{ Last DMT recorded classified on the basis of the place of administration, $n(\%)$} \\
\hline At hospital & $248(31.84)$ & $332(21.31)$ & $<0.0001$ \\
\hline At home & $434(55.71)$ & $988(63.41)$ & \\
\hline Never treated & $97(12.45)$ & $238(15.28)$ & \\
\hline \multicolumn{4}{|l|}{ DMT sequences, $\mathrm{n}(\%)$} \\
\hline Never treated & $111(14.25)$ & $258(16.56)$ & 0.0001 \\
\hline
\end{tabular}


Table 1 Demographic and Clinical Characteristics of PwMS With COVID-19 (Cases) and PwMS Without COVID-19 (Controls) (continued)

\begin{tabular}{lll}
\hline Variable & $\begin{array}{l}\text { PwMS with COVID-19 } \\
(\mathbf{n}=\mathbf{7 7 9 )}\end{array}$ & $\begin{array}{l}\text { PwMS without COVID-19 } \\
(\mathbf{n}=\mathbf{1 , 5 5 8 )}\end{array}$ \\
\hline Only high efficacy DMTs & $142(18.23)$ & $243(15.60)$ \\
\hline Moderate efficacy DMTs followed by high-efficacy DMTs & $235(30.17)$ & $360(23.11)$ \\
\hline Only moderate efficacy DMTs & $291(37.36)$ & $697(44.74)$ \\
\hline
\end{tabular}

Abbreviations: DMT = disease-modifying therapy; PwMS = people with multiple sclerosis.

PwMS, we have built a case-control study embedded in a national MS registry to evaluate the risk factors associated with becoming infected by SARS-CoV-2. The use of a disease registry has allowed us to analyze data about the whole disease and treatment history, including crucial information on the exposure duration to each DMT and the type of treatment sequencing received, in patients with and without COVID-19.

In our case-control study, PwMS who developed COVID-19 were younger, more frequently female individuals, less disabled, and with more active disease in comparison with PwMS who did not develop COVID-19. These findings suggest that younger PwMS with lower levels of disability might have had a higher number of social interactions and those with a higher disease activity an increased need to attend clinics for corticosteroid therapy or for changes in therapy, both of which exposed individuals to higher risk of SARS-CoV-2 infection.

Moreover, our results highlight that patients who received natalizumab are at high risk of acquiring COVID-19. We can speculate that PwMS who need to periodically visit the MS clinic to receive DMT, as for the monthly administration of natalizumab, and/or who need to undergo more frequent blood examinations might have a greater number of environmental (hospital) exposures that are undoubtedly one of the major risk factors for developing a highly contagious viral respiratory disease. ${ }^{21}$

Since the pandemic spread in March 2020, many changes have been implemented in an attempt to reduce the risk of SARS-CoV-2 infection associated with indoor environments such as hospital waiting rooms. ${ }^{22}$ This has included the use of telemedicine. ${ }^{23}$ However, patients receiving infusion DMT or treatment requiring periodic monitoring have had to attend the hospital for drug administration, the laboratory for blood testing, or the radiology unit for MRI. The risk of acquiring COVID-19 during outpatient consultations or while receiving an infusion therapy has not been reported so far but is a matter of active investigation. ${ }^{24}$

Of most importance, we found the risk of getting COVID-19 was higher in those who underwent an escalation treatment strategy with a history of multiple exposures to immunotherapy, which may have chronically modified the immune system and overall susceptibility to infection. ${ }^{14}$ Some DMTs, indeed, are associated with long-lasting effects on the immune system, ${ }^{25-28}$ which can combine with the effects of subsequent therapies. These results prompt a safety evaluation of escalation therapy in the context of the potential risk of infection associated with previous or sequential immunosuppression during any treatment decision. ${ }^{14}$

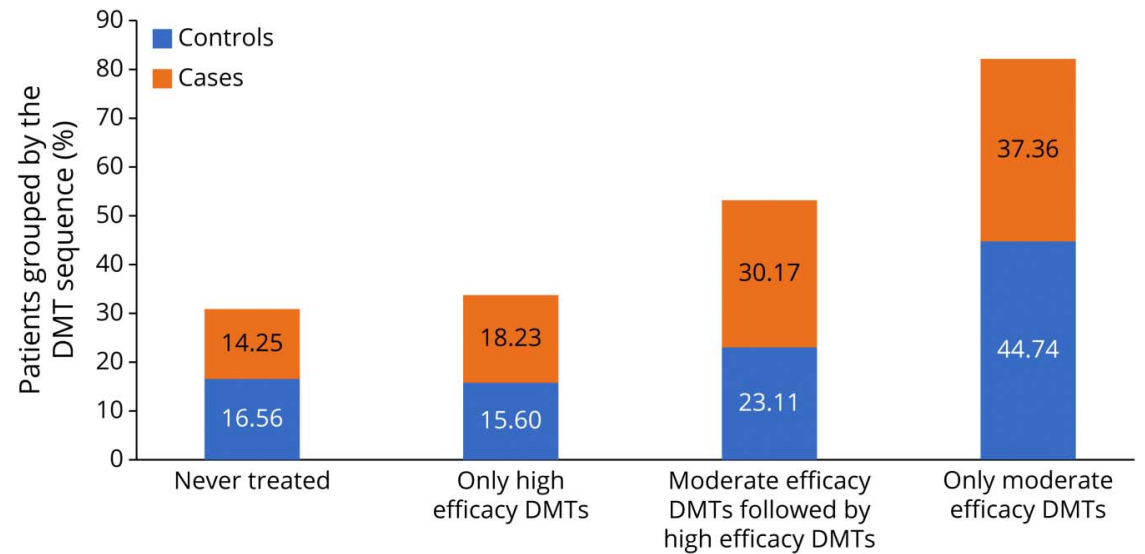

Blue bars represent controls, and orange bars represent cases. PwMS = people with multiple sclerosis. 
Table 2 ORs for Risk of COVID-19 Infection Among People With Multiple Sclerosis_Logistic Regression Model Including the Last Recorded DMT

\begin{tabular}{|c|c|c|c|}
\hline Covariate & OR & $95 \% \mathrm{Cl}$ & $p$ Value \\
\hline Female sex & 1.25 & $1.03-1.51$ & 0.02 \\
\hline Presence of comorbidities & 1.69 & $1.18-2.40$ & 0.004 \\
\hline Patients with at least 1 relapse in the previous year & 1.25 & $0.93-1.69$ & 0.14 \\
\hline Progressive disease course & 0.87 & $0.61-1.24$ & 0.45 \\
\hline \multicolumn{4}{|l|}{ Disease duration, classes ( $\leq 10$ years as reference) } \\
\hline $11-20$ & 1.19 & $0.95-1.48$ & 0.13 \\
\hline$>\mathbf{2 0}$ & 1.17 & $0.88-1.56$ & 0.27 \\
\hline Age & 0.9 & $0.86-0.95$ & $<0.0001$ \\
\hline EDSS score & 0.95 & $0.90-1.01$ & 0.11 \\
\hline \multicolumn{4}{|l|}{ Last DMT recorded, never treated as reference } \\
\hline Alemtuzumab & 1.47 & $0.73-2.93$ & 0.28 \\
\hline Azatioprine & 1.58 & $0.79-3.14$ & 0.19 \\
\hline Cladribine & 1.68 & $0.89-3.20$ & 0.11 \\
\hline Cyclophosphamide & 1.42 & $0.42-4.85$ & 0.57 \\
\hline Dimethyl fumarate & 1.31 & $0.93-1.84$ & 0.12 \\
\hline Fingolimod & 1.21 & $0.84-1.75$ & 0.31 \\
\hline Glatiramer acetate & 0.87 & $0.59-1.29$ & 0.49 \\
\hline Interferon beta products & 0.84 & $0.60-1.17$ & 0.30 \\
\hline Methotrexate & 1.36 & $0.47-3.97$ & 0.57 \\
\hline Mitoxantrone & 1.03 & $0.28-3.84$ & 0.96 \\
\hline Natalizumab & 2.38 & $1.66-3.42$ & $<0.0001$ \\
\hline Ocrelizumab & 1.39 & $0.94-2.06$ & 0.10 \\
\hline Rituximab & 1.4 & $0.74-2.64$ & 0.30 \\
\hline Teriflunomide & 0.97 & $0.60-1.56$ & 0.90 \\
\hline
\end{tabular}

Abbreviation: DMT = disease-modifying therapy.

Covariates found to be significant in the model are marked in bold.

Various limitations of this study deserve discussion. We did not collect data regarding socioeconomic or worker status that might contribute to the risk of COVID-19 infection. Furthermore, reporting of COVID-19 cases by health-care professionals was voluntary, which may have biased the results toward patients who more frequently attended clinics to receive the DMT infusions, which would overestimate the risk among patients receiving DMT at the hospital. Nevertheless, the study design we chose, which allowed us to randomly select controls from the entire IMSR database based on the region of residence and date of the last recorded visit, enabled us to mitigate the effect of such bias.

As the secondary objective, we replicated previous studies in assessing the risk factors associated with COVID-19 severity in PwMS. We confirmed the clinical characteristics, the distribution of clinical outcomes, and the main risk factors associated with the severity of COVID-19, which have been consistently reported in previous studies, despite the definitions of COVID-19 severity differing between them. ${ }^{4-9}$ Most $(\mathrm{n}=643,82.5 \%)$ of our patients reported a mild COVID-19 course, which is consistent with findings from the Italian program $^{4}$ and the Spanish registry ${ }^{8}$ in which $85 \%$ and $76 \%$ of patients, respectively, presented with mild infection. In keeping with previous studies, ${ }^{4-9}$ PwMS experiencing a severe COVID-19 course were significantly older, more often male individuals, more disabled, and more frequently found to have a progressive form of MS in comparison with patients affected by a mild or moderate COVID-19 disease course. The multivariable Poisson regression model revealed older age, a 
Table 3 ORs for Risk of COVID-19 Infection Among People With Multiple Sclerosis-Logistic Regression Model Including the DMT Sequences

\begin{tabular}{|c|c|c|c|}
\hline Covariate & OR & $95 \% \mathrm{Cl}$ & $p$ Value \\
\hline Female sex & 1.27 & $1.04-1.51$ & 0.02 \\
\hline Presence of comorbidities & 1.72 & $1.22-2.44$ & 0.002 \\
\hline Patients with at least 1 relapse in the previous year & 1.25 & $0.93-1.68$ & 0.14 \\
\hline Progressive disease course & 0.83 & $0.59-1.17$ & 0.29 \\
\hline \multicolumn{4}{|l|}{ Disease duration, classes ( $\leq 10$ years as reference) } \\
\hline $11-20$ & 1.12 & $0.90-1.40$ & 0.32 \\
\hline$>20$ & 1.07 & $0.80-1.43$ & 0.64 \\
\hline Age & 0.89 & $0.85-0.93$ & $<0.0001$ \\
\hline EDSS score & 0.96 & $0.91-1.02$ & 0.19 \\
\hline \multicolumn{4}{|l|}{ DMT sequences, never treated as reference } \\
\hline Only high efficacy DMTs & 1.33 & $0.97-1.83$ & 0.08 \\
\hline Moderate efficacy DMTs followed by high efficacy DMTs & 1.57 & $1.16-2.13$ & 0.004 \\
\hline Only moderate efficacy DMTs & 0.99 & $0.75-1.30$ & 0.93 \\
\hline
\end{tabular}

Abbreviation: DMT = disease-modifying therapy.

Covariates found to be significant in the model are marked in bold.

progressive course, and the presence of comorbidities (even if the latter did not reach statistical significance) as being the most important factors associated with a higher risk of severe course of COVID-19, whereas interferon beta treatment and no treatment were associated with a lower risk of infection, as previously reported. ${ }^{4,5,7}$ We did not confirm the association between a severe COVID-19 outcome and anti-CD20 drug exposure, as reported in other studies. ${ }^{4,6,7}$ An explanation of these different results may be because the percentage of patients receiving anti-CD20 drugs was lower in our cohort (8.99\%) in comparison with that reported in studies that found the association of these drugs with severe COVID-19 $\left(11.1 \%,{ }^{4} 35.8 \%{ }^{6}\right)$. Moreover, in our study, we used a more rigorous criterion of treatment exposure; indeed, only anti-

Table 4 ORs for Risk of COVID-19 Infection Among People With Multiple Sclerosis_Last DMT Recorded Classified on the Basis of the Place of Administration

\begin{tabular}{|c|c|c|c|}
\hline Covariate & OR & $95 \% \mathrm{Cl}$ & $p$ Value \\
\hline Female sex & 1.25 & $1.03-1.51$ & 0.02 \\
\hline Presence of comorbidities & 1.74 & $1.22-2.46$ & 0.002 \\
\hline Patients with at least 1 relapse in the previous year & 1.26 & $0.94-1.69$ & 0.13 \\
\hline Progressive disease course & 0.83 & $0.59-1.16$ & 0.27 \\
\hline \multicolumn{4}{|l|}{ Disease duration, classes ( $\leq 10$ years as reference) } \\
\hline $11-20$ & 1.18 & $0.95-1.47$ & 0.73 \\
\hline$>20$ & 1.16 & $0.88-1.54$ & 0.13 \\
\hline Age & 0.89 & $0.85-0.93$ & $<0.0001$ \\
\hline EDSS score & 0.96 & $0.90-1.02$ & 0.13 \\
\hline \multicolumn{4}{|c|}{ Last DMT recorded classified on the basis of the place of administration, never treated as reference } \\
\hline At hospital & 1.65 & $1.34-2.04$ & $<0.0001$ \\
\hline At home & 0.94 & $0.71-1.24$ & 0.65 \\
\hline
\end{tabular}


Table 5 Demographic and Clinical Characteristics by the Clinical Course of COVID-19

\begin{tabular}{|c|c|c|c|c|}
\hline \multirow[b]{2}{*}{ Variable } & \multicolumn{3}{|c|}{ COVID-19 symptoms severity } & \multirow[b]{2}{*}{$p$ Value } \\
\hline & Mild $(n=643)$ & Moderate $(n=116)$ & Severe $(n=20)$ & \\
\hline Age, median (IQR), y & $41.80(32.70-50.60)$ & $43.20(33.20-50.30)$ & $59.10(53.25-63.55)$ & $<0.0001$ \\
\hline Patients with comorbidities, $\mathrm{n}(\%)$ & $53(8.24)$ & $7(6.03)$ & $4(20.00)$ & 0.1099 \\
\hline Disease duration, y & $11.20(5.15-17.80)$ & $10.80(4.70-19.60)$ & $15.70(5.80-24.35)$ & 0.2676 \\
\hline Male sex, n (\%) & $193(30.02)$ & $31(26.72)$ & $11(55.00)$ & 0.0385 \\
\hline EDSS score, median (IQR) & $2.00(1.00-3.50)$ & $2.00(1.00-3.50)$ & $4.50(2.75-6.50)$ & 0.0003 \\
\hline Number of EDSS scores, median (IQR) & $11.00(5.00-21.00)$ & $8.00(4.00-17.00)$ & $9.50(5.00-21.00)$ & 0.0782 \\
\hline Patients with at least 1 relapse in the previous year, $n(\%)$ & $77(11.98)$ & $17(14.66)$ & $1(5.00)$ & 0.4379 \\
\hline \multicolumn{5}{|l|}{ Disease course } \\
\hline Relapsing & $560(87.09)$ & $102(87.93)$ & $10(50.00)$ & $<0.0001$ \\
\hline Progressive & $56(8.71)$ & $12(10.34)$ & $10(50.00)$ & \\
\hline Missing & $27(4.20)$ & $2(1.72)$ & $0(0.00)$ & \\
\hline \multicolumn{5}{|l|}{ Last DMT recorded, $\mathrm{n}(\%)$} \\
\hline Alemtuzumab & $13(2.02)$ & $3(2.59)$ & $0(0.00)$ & 0.1758 \\
\hline Teriflunomide & $27(4.20)$ & $4(3.45)$ & $2(10.00)$ & \\
\hline Azatioprine & $11(1.71)$ & $3(2.59)$ & $1(5.00)$ & \\
\hline Dimethyl fumarate & $94(14.62)$ & $19(16.38)$ & $4(20.00)$ & \\
\hline Glatiramer acetate & $48(7.47)$ & $6(5.17)$ & $2(10.00)$ & \\
\hline Cyclophosphamide & $3(0.47)$ & $1(0.86)$ & $0(0.00)$ & \\
\hline Fingolimod & $68(10.58)$ & $13(11.21)$ & $2(10.00)$ & \\
\hline Methotrexate & $2(0.31)$ & $2(1.72)$ & $1(5.00)$ & \\
\hline Natalizumab & $120(18.66)$ & $15(12.93)$ & $2(10.00)$ & \\
\hline Mitoxantrone & $1(0.16)$ & $2(1.72)$ & $0(0.00)$ & \\
\hline Interferon beta products & $92(14.31)$ & $11(9.48)$ & $1(5.00)$ & \\
\hline Rituximab & $14(2.18)$ & $4(3.45)$ & $0(0.00)$ & \\
\hline Ocrelizumab & $55(8.55)$ & $11(9.48)$ & $4(20.00)$ & \\
\hline Cladribine & $19(2.95)$ & $2(1.72)$ & $0(0.00)$ & \\
\hline Never treated & $76(11.82)$ & $20(17.24)$ & $1(5.00)$ & \\
\hline
\end{tabular}

Abbreviation: $\mathrm{DMT}=$ disease-modifying therapy.

CD20 drugs administered for a minimum of 30 days were considered in the analysis to prevent the possibility of assigning an increased risk of Sars-Cov- 2 infection to a DMT administered only for a few days.

In conclusion, data from the IMSR seem to suggest that the risk of contracting COVID-19 in PwMS may be more linked to the cumulative effect of sequences of different immunotherapies than to the type of the last administered treatment. Furthermore, patients with MS treated with DMT administered at MS clinics, who are more often younger and with higher disease activity, are at higher risk of being infected by COVID-19 compared with those taking oral or injectable therapies at home. Further studies assessing the safety of the escalation therapy approach and the risk of infections associated with previous or sequential immunosuppression are needed to improve treatment decision-making in clinical practice.

Studies of alternative administration routes for some drugs currently requiring a higher frequency of hospital attendance are also needed. In fact, 2 studies suggested that natalizumab 
Table 6 Multivariable Poisson Regression Model for Severe COVID-19 Infection

\begin{tabular}{|c|c|c|c|}
\hline Risk factor & IRR & $95 \% \mathrm{Cl}$ & $p$ Value \\
\hline Male sex & 1.92 & $0.73-5.05$ & 0.1889 \\
\hline Presence of comorbidities & 3.12 & 0.9810 .00 & 0.0556 \\
\hline Patients with at least 1 relapse in the previous year & 1.20 & $0.17-8.68$ & 0.8539 \\
\hline Progressive disease course & 5.32 & $1.59-17.79$ & 0.0067 \\
\hline \multicolumn{4}{|l|}{ Disease duration, classes ( $\leq 10$ years as reference) } \\
\hline $11-20$ & 0.43 & $0.13-1.42$ & 0.168 \\
\hline$>\mathbf{2 0}$ & 0.30 & $0.08-1.22$ & 0.0932 \\
\hline Age & 1.09 & 1.04-1.15 & 0.0004 \\
\hline EDSS score & 1.23 & $0.93-1.64$ & 0.1503 \\
\hline \multicolumn{4}{|c|}{ Last DMT recorded, dimethyl fumarate treated as reference } \\
\hline Azatioprine & 0.21 & $0.02-2.11$ & 0.5375 \\
\hline Fingolimod & 0.89 & $0.17-4.52$ & 0.8867 \\
\hline Glatiramer acetate & 0.63 & $0.12-3.43$ & 0.5941 \\
\hline Interferon beta products & 0.11 & $0.01-0.97$ & 0.0476 \\
\hline Methotrexate & 0.17 & $0.02-1.78$ & 0.1404 \\
\hline Natalizumab & 0.63 & $0.12-3.26$ & 0.5796 \\
\hline Ocrelizumab & 0.35 & $0.07-1.63$ & 0.1801 \\
\hline Teriflunomide & 0.52 & $0.08-3.40$ & 0.4939 \\
\hline Never treated & 0.09 & $0.01-0.85$ & 0.0356 \\
\hline
\end{tabular}

Abbreviations: DMT = disease-modifying therapy; IRR = incidence rate ratio.

Covariates found to be significant in the model are marked in bold.

administered subcutaneously was comparable with IV dosing regarding efficacy, pharmacokinetics/pharmacodynamics, and safety, while needing a shorter time of hospital attendence. ${ }^{29,30}$ An increased use of telemedicine ${ }^{23}$ and greater attention to the safety of indoor environments, ${ }^{22}$ such as hospital waiting rooms, could contribute to minimizing the risk of COVID-19.

Finally, this study does not confirm a critical role of current MS therapies in the severity of COVID-19. The study supports earlier findings that older PwMS with progressive disease and greater disability are at a higher risk of severe COVID-19 and that interferon beta exposure decreases this risk. ${ }^{4-9}$ A more correct assessment of the relationship between DMT exposure duration and the risk of contracting COVID-19, and of COVID-19 severe outcomes, especially now that new variants of coronavirus are emerging, remains a crucial goal.

\section{Acknowledgment}

The authors thank the network of Research Assistance of the Italian MS Register for their valuable contribution in data collection.

\section{Study Funding}

The authors report no targeted funding.

\section{Disclosure}

All the authors report no competing interest related to this specific project. The authors report no conflicts of interest regarding the contents of this study but note that the patients in the study were treated with a number of diseasemodifying drugs and that authors P.I., A.M., D.P., F.P., M.C., V.B.M., P.S., I.P., G. Lus, G.D.L., A.L., P.C., S.M., G.T.M., F.G., P.R., M.V., L.B., R.T., L.M., S.M., D.F., G.T., G.C., M.F., M.P.A., and M.T. have received advisory board/ speakers honoraria, travel support, research grants, consulting fees, or clinical trial support from the manufacturers of those drugs, including Actelion, Allergan, Almirall, Bayer Schering, Biogen, Celgene, Excemed, Genzyme, Forward Pharma, Ipsen, Medday, Merck, Merz, Mylan, Novartis, Sanofi, Roche, Teva, and their local affiliates.Go to Neurology.org/NN for full disclosures.

\section{Publication History}

Received by Neurology: Neuroimmunology \& Neuroinflammation August 12, 2021. Accepted in final form December 15, 2021. 
Appendix 1 Authors

\begin{tabular}{|c|c|c|}
\hline Name & Location & Contribution \\
\hline $\begin{array}{l}\text { Pietro } \\
\text { laffaldano, } \\
\text { MD }\end{array}$ & $\begin{array}{l}\text { Department of Basic } \\
\text { Medical Sciences, } \\
\text { Neurosciences and Sense } \\
\text { Organs, University of Bari } \\
\text { Aldo Moro, Bari, Italy }\end{array}$ & $\begin{array}{l}\text { Drafting/revision of the } \\
\text { article for content, including } \\
\text { medical writing for content; } \\
\text { major role in the acquisition } \\
\text { of data; study concept or } \\
\text { design; and analysis or } \\
\text { interpretation of data }\end{array}$ \\
\hline
\end{tabular}

\begin{tabular}{|c|c|c|}
\hline $\begin{array}{l}\text { Giuseppe } \\
\text { Lucisano, } \\
\text { MSc Stat }\end{array}$ & CORESEARCH, Pescara, Italy & $\begin{array}{l}\text { Drafting/revision of the } \\
\text { article for content, including } \\
\text { medical writing for content; } \\
\text { major role in the acquisition } \\
\text { of data; study concept or } \\
\text { design; and analysis or } \\
\text { interpretation of data }\end{array}$ \\
\hline $\begin{array}{l}\text { Alessia } \\
\text { Manni, MD }\end{array}$ & $\begin{array}{l}\text { Department of Basic } \\
\text { Medical Sciences, } \\
\text { Neurosciences and Sense } \\
\text { Organs, University of Bari } \\
\text { Aldo Moro, Bari, Italy }\end{array}$ & $\begin{array}{l}\text { Drafting/revision of the } \\
\text { article for content, including } \\
\text { medical writing for content; } \\
\text { major role in the acquisition } \\
\text { of data; and analysis or } \\
\text { interpretation of data }\end{array}$ \\
\hline
\end{tabular}

Damiano Department of Basic Major role in the acquisition Paolicelli, MD Medical Sciences, of data; drafting/revision of Neurosciences and Sense the article for content Organs, University of Bari Aldo Moro, Bari, Italy

\begin{tabular}{|c|c|c|}
\hline $\begin{array}{l}\text { Francesco } \\
\text { Patti, MD }\end{array}$ & $\begin{array}{l}\text { Dipartimento di Scienze } \\
\text { Mediche e Chirurgiche e } \\
\text { Tecnologie Avanzate, GF } \\
\text { Ingrassia, Sez. } \\
\text { Neuroscienze, Centro } \\
\text { Sclerosi Multipla, Università } \\
\text { di Catania }\end{array}$ & $\begin{array}{l}\text { Major role in the acquisition } \\
\text { of data }\end{array}$ \\
\hline $\begin{array}{l}\text { Marco } \\
\text { Capobianco, } \\
\text { MD }\end{array}$ & $\begin{array}{l}\text { SCDO Neurologia e Centro } \\
\text { di Riferimento Regionale } \\
\text { Sclerosi Multipla (CRESM), } \\
\text { AOU San Luigi-Orbassano } \\
\text { (TO), Italy }\end{array}$ & $\begin{array}{l}\text { Major role in the acquisition } \\
\text { of data }\end{array}$ \\
\hline $\begin{array}{l}\text { Vincenzo } \\
\text { Brescia } \\
\text { Morra, MD }\end{array}$ & $\begin{array}{l}\text { Department of } \\
\text { Neurosciences, } \\
\text { Reproductive and } \\
\text { Odontostomatological } \\
\text { Sciences, 'Federico II' } \\
\text { University of Naples, Italy }\end{array}$ & $\begin{array}{l}\text { Major role in the acquisition } \\
\text { of data }\end{array}$ \\
\hline $\begin{array}{l}\text { Patrizia Sola, } \\
\text { MD }\end{array}$ & $\begin{array}{l}\text { Centro malattie } \\
\text { Demielinizzanti, Azienda } \\
\text { Ospedaliera Universitaria di } \\
\text { Modena/OCB, UO } \\
\text { Neurologia, Italy }\end{array}$ & $\begin{array}{l}\text { Major role in the acquisition } \\
\text { of data }\end{array}$ \\
\hline $\begin{array}{l}\text { Ilaria Pesci, } \\
\text { MD }\end{array}$ & $\begin{array}{l}\text { Centro SM UO Neurologia, } \\
\text { Ospedale Di Vaio, Fidenza, } \\
\text { AUSL PR, Italy }\end{array}$ & $\begin{array}{l}\text { Major role in the acquisition } \\
\text { of data }\end{array}$ \\
\hline $\begin{array}{l}\text { Giacomo Lus, } \\
\text { MD }\end{array}$ & $\begin{array}{l}\text { Multiple Sclerosis Center, II } \\
\text { Division of Neurology, } \\
\text { Department of Clinical and } \\
\text { Experimental Medicine, Second } \\
\text { University of Naple, Italy }\end{array}$ & $\begin{array}{l}\text { Major role in the acquisition } \\
\text { of data }\end{array}$ \\
\hline $\begin{array}{l}\text { Giovanna De } \\
\text { Luca, MD }\end{array}$ & $\begin{array}{l}\text { Centro Sclerosi Multipla, } \\
\text { Clinica Neurologica, } \\
\text { Policlinico SS. Annunziata, } \\
\text { Chieti, Italy }\end{array}$ & $\begin{array}{l}\text { Major role in the acquisition } \\
\text { of data }\end{array}$ \\
\hline $\begin{array}{l}\text { Alessandra } \\
\text { Lugaresi, MD }\end{array}$ & $\begin{array}{l}\text { IRCCS Istituto delle Scienze } \\
\text { Neurologiche di Bologna, } \\
\text { UOSI Riabilitazione Sclerosi } \\
\text { Multipla, Bologna, Italy }\end{array}$ & $\begin{array}{l}\text { Major role in the acquisition } \\
\text { of data }\end{array}$ \\
\hline
\end{tabular}

Appendix 1 (continued)

\begin{tabular}{|c|c|c|}
\hline Name & Location & Contribution \\
\hline $\begin{array}{l}\text { Paola } \\
\text { Cavalla, MD }\end{array}$ & $\begin{array}{l}\text { Centro SM - Neurologia } 1 \\
\text { D.U.-AOU Citta' Della } \\
\text { Salute E Della Scienza Di } \\
\text { Torino, Italy }\end{array}$ & $\begin{array}{l}\text { Major role in the acquisition } \\
\text { of data }\end{array}$ \\
\hline $\begin{array}{l}\text { Sara } \\
\text { Montepietra, } \\
\text { MD }\end{array}$ & $\begin{array}{l}\text { Centro SM, S.O.C. } \\
\text { Neurologia, Arcispedale } \\
\text { Santa Maria Nuova, AUSL- } \\
\text { IRCCS Reggio Emilia, Italy }\end{array}$ & $\begin{array}{l}\text { Major role in the acquisition } \\
\text { of data }\end{array}$ \\
\hline $\begin{array}{l}\text { Giorgia } \\
\text { Teresa } \\
\text { Maniscalco, } \\
\text { MD }\end{array}$ & $\begin{array}{l}\text { Neurological Clinic and Multiple } \\
\text { Sclerosis Center, A Cardarelli } \\
\text { Hospital, Naples, Italy }\end{array}$ & $\begin{array}{l}\text { Major role in the acquisition } \\
\text { of data }\end{array}$ \\
\hline $\begin{array}{l}\text { Franco } \\
\text { Granella, MD }\end{array}$ & $\begin{array}{l}\text { Centro Sclerosi } \\
\text { Multipla-Azienda } \\
\text { Ospedaliero-Universitaria di } \\
\text { Parma, Italy }\end{array}$ & $\begin{array}{l}\text { Major role in the acquisition } \\
\text { of data }\end{array}$ \\
\hline
\end{tabular}

\begin{tabular}{lll}
\hline $\begin{array}{l}\text { Paolo } \\
\text { Ragonese, } \\
\text { MD }\end{array}$ & $\begin{array}{l}\text { Department of Biomedicine, } \\
\text { Neuroscience and Advanced } \\
\text { Diagnostics, University of } \\
\text { Palermo }\end{array}$ & $\begin{array}{l}\text { Major role in the acquisition } \\
\text { of data }\end{array}$ \\
\hline $\begin{array}{l}\text { Marika } \\
\text { Vianello, MD }\end{array}$ & $\begin{array}{l}\text { Centro Sclerosi Multipla UO } \\
\text { Neurologia-Ospedale, } \\
\text { Treviso, Italy }\end{array}$ & $\begin{array}{l}\text { Major role in the acquisition } \\
\text { of data }\end{array}$ \\
\hline $\begin{array}{l}\text { Laura } \\
\text { Brambilla, } \\
\text { MD }\end{array}$ & $\begin{array}{l}\text { Fondazione IRCCS Istituto } \\
\text { Neurologico "C. Besta" U.O. }\end{array}$ & $\begin{array}{l}\text { Major role in the acquisition } \\
\text { of data }\end{array}$ \\
& $\begin{array}{l}\text { Neuroimmunologia e Malattie } \\
\text { Neuromuscolari, Italy }\end{array}$ &
\end{tabular}

Rocco Totaro, Centro Malattie Major role in the acquisition

$\begin{array}{lll}\text { MD } & \text { Demielinizzanti-Clinica of data } \\ & \text { Neurologica, Ospedale San } & \\ & \text { Salvatore-L'Aquila, Italy }\end{array}$

\begin{tabular}{lll}
\hline $\begin{array}{l}\text { Simona } \\
\text { Toscano, MD }\end{array}$ & $\begin{array}{l}\text { Dipartimento di Scienze } \\
\text { Mediche e Chirurgiche e } \\
\text { Tecnologie Avanzate, GF } \\
\text { Ingrassia, Sez. }\end{array}$ & $\begin{array}{l}\text { Major role in the acquisition } \\
\text { of data }\end{array}$ \\
& $\begin{array}{l}\text { Neuroscienze, Centro } \\
\text { Sclerosi Multipla, Università } \\
\text { di Catania, Italy }\end{array}$ & \\
\hline Simona & SCDO Neurologia e Centro & Major role in the acquisition \\
Malucchi, MD & $\begin{array}{l}\text { di Riferimento Regionale } \\
\text { Sclerosi Multipla (CRESM), }\end{array}$ & \\
& $\begin{array}{l}\text { AOU San Luigi-Orbassano } \\
\text { (TO), Italy }\end{array}$ &
\end{tabular}

\begin{tabular}{lll}
\hline Maria & $\begin{array}{l}\text { Department of } \\
\text { Petracca, MD }\end{array}$ & $\begin{array}{l}\text { Major role in the acquisition } \\
\text { Neurosciences, Reproductive } \\
\text { and Odontostomatological }\end{array}$ \\
& Sciences, "Federico II" & \\
& University of Naples, Italy &
\end{tabular}

Lucia Moiola, Dipartimento di Neurologia, Major role in the acquisition MD Neurofisiologia e of data Neuroriabilitazione, San Raffaele Scientific Institute, Vita-Salute San Raffaele University, Milan

\begin{tabular}{lll}
\hline $\begin{array}{l}\text { Diana } \\
\text { Ferraro, MD }\end{array}$ & $\begin{array}{l}\text { Department of Biomedical, } \\
\text { Metabolic and } \\
\text { Neurosciences, University of } \\
\text { Modena and Reggio Emilia, } \\
\text { Modena, Italy }\end{array}$ & $\begin{array}{l}\text { Major role in the acquisition } \\
\text { of data }\end{array}$ \\
\hline $\begin{array}{l}\text { Vito Lepore, } \\
\text { MD }\end{array}$ & $\begin{array}{l}\text { Istituto di Ricerche } \\
\text { Farmacologiche Mario Negri } \\
\text { IRCCS, Milano, Italy }\end{array}$ & $\begin{array}{l}\text { Major role in the acquisition } \\
\text { of data }\end{array}$ \\
&
\end{tabular}


Appendix 1 (continued)

\begin{tabular}{|c|c|c|}
\hline Name & Location & Contribution \\
\hline $\begin{array}{l}\text { Paola } \\
\text { Mosconi, Biol } \\
\text { Sci D }\end{array}$ & $\begin{array}{l}\text { Istituto di Ricerche } \\
\text { Farmacologiche Mario Negri } \\
\text { IRCCS, Milano, Italy }\end{array}$ & $\begin{array}{l}\text { Major role in the acquisition } \\
\text { of data }\end{array}$ \\
\hline $\begin{array}{l}\text { Michela } \\
\text { Ponzio, PhD }\end{array}$ & $\begin{array}{l}\text { Scientific Research Area, } \\
\text { Italian Multiple Sclerosis } \\
\text { Foundation, Genoa, Italy }\end{array}$ & $\begin{array}{l}\text { Major role in the acquisition } \\
\text { of data }\end{array}$ \\
\hline $\begin{array}{l}\text { Gioacchino } \\
\text { Tedeschi, MD }\end{array}$ & $\begin{array}{l}\text { First Division of Neurology, } \\
\text { Department of Advanced } \\
\text { Medical and Surgical } \\
\text { Sciences, MRI Research } \\
\text { Center SUN-FISM, AOU, } \\
\text { University of Campania } \\
\text { "Luigi Vanvitelli," Naples, } \\
\text { Italy }\end{array}$ & $\begin{array}{l}\text { Major role in the acquisition } \\
\text { of data }\end{array}$ \\
\hline $\begin{array}{l}\text { Giancarlo } \\
\text { Comi, MD }\end{array}$ & $\begin{array}{l}\text { Institute of Experimental } \\
\text { Neurology, IRCCS San } \\
\text { Raffaele Hospital, Milan, } \\
\text { Italy }\end{array}$ & $\begin{array}{l}\text { Major role in the acquisition } \\
\text { of data }\end{array}$ \\
\hline $\begin{array}{l}\text { Mario } \\
\text { Alberto } \\
\text { Battaglia, MD }\end{array}$ & $\begin{array}{l}\text { Department of Life Sciences, } \\
\text { University of Siena, Italy }\end{array}$ & $\begin{array}{l}\text { Major role in the acquisition } \\
\text { of data }\end{array}$ \\
\hline $\begin{array}{l}\text { Massimo } \\
\text { Filippi, MD }\end{array}$ & $\begin{array}{l}\text { Dipartimento di Neurologia, } \\
\text { Neurofisiologia e } \\
\text { Neuroriabilitazione, San } \\
\text { Raffaele Scientific Institute, } \\
\text { Vita-Salute San Raffaele } \\
\text { University, Milan, Italy }\end{array}$ & $\begin{array}{l}\text { Major role in the acquisition } \\
\text { of data }\end{array}$ \\
\hline $\begin{array}{l}\text { Maria Pia } \\
\text { Amato, MD }\end{array}$ & $\begin{array}{l}\text { Department NEUROFARBA, } \\
\text { University of Florence, Italy }\end{array}$ & $\begin{array}{l}\text { Major role in the acquisition } \\
\text { of data; drafting/revision of } \\
\text { the article for content }\end{array}$ \\
\hline $\begin{array}{l}\text { Maria } \\
\text { Trojano, MD }\end{array}$ & $\begin{array}{l}\text { Department of Basic } \\
\text { Medical Sciences, } \\
\text { Neurosciences and Sense } \\
\text { Organs, University of Bari } \\
\text { Aldo Moro, Bari, Italy }\end{array}$ & $\begin{array}{l}\text { Drafting/revision of the } \\
\text { article for content, including } \\
\text { medical writing for content; } \\
\text { major role in the acquisition } \\
\text { of data; study concept or } \\
\text { design; and analysis or } \\
\text { interpretation of data }\end{array}$ \\
\hline
\end{tabular}

Appendix 2 Coinvestigators

\begin{tabular}{|c|c|c|c|}
\hline Name & Location & Role & Contribution \\
\hline $\begin{array}{l}\text { Daniele } \\
\text { Spitaleri, MD }\end{array}$ & $\begin{array}{l}\text { AORN San G. Moscati Centro } \\
\text { Sclerosi Multipla, U.O.C. } \\
\text { Neurologia, Avellino, Italy }\end{array}$ & $\begin{array}{l}\text { Site } \\
\text { investigator }\end{array}$ & $\begin{array}{l}\text { Acquisition of } \\
\text { data }\end{array}$ \\
\hline $\begin{array}{l}\text { Maurizia } \\
\text { Gatto, MD }\end{array}$ & $\begin{array}{l}\text { Ospedale Generale } \\
\text { Regionale F. Miulli Centro } \\
\text { Malattie Demielinizzanti, } \\
\text { Bari, Italy }\end{array}$ & $\begin{array}{l}\text { Site } \\
\text { investigator }\end{array}$ & $\begin{array}{l}\text { Acquisition of } \\
\text { data }\end{array}$ \\
\hline $\begin{array}{l}\text { Bonaventura } \\
\text { Ardito, MD }\end{array}$ & $\begin{array}{l}\text { Ospedale Della Murgia Fabio } \\
\text { Perinei, Centro Sclerosi } \\
\text { Multipla, Altamura, Italy }\end{array}$ & $\begin{array}{l}\text { Site } \\
\text { investigator }\end{array}$ & $\begin{array}{l}\text { Acquisition of } \\
\text { data }\end{array}$ \\
\hline $\begin{array}{l}\text { Valeria } \\
\text { Barcella, MD }\end{array}$ & $\begin{array}{l}\text { Ospedale Papa Giovanni } \\
\text { XXIII, Centro Provinciale } \\
\text { Sclerosi Multipla, USS } \\
\text { Malattie Autoimmuni, } \\
\text { Bergamo, Italy }\end{array}$ & $\begin{array}{l}\text { Site } \\
\text { investigator }\end{array}$ & $\begin{array}{l}\text { Acquisition of } \\
\text { data }\end{array}$ \\
\hline $\begin{array}{l}\text { Lorenzo } \\
\text { Capone, MD }\end{array}$ & $\begin{array}{l}\text { MD, Ospedale degli Infermi, } \\
\text { Centro Clinico delle Malattie } \\
\text { Demielinizzanti dell'ASL di } \\
\text { Biella, Biella, Italy }\end{array}$ & $\begin{array}{l}\text { Site } \\
\text { investigator }\end{array}$ & $\begin{array}{l}\text { Acquisition of } \\
\text { data }\end{array}$ \\
\hline
\end{tabular}

Appendix 2 (continued)

\begin{tabular}{llll}
\hline Name & Location & Role & Contribution \\
\hline $\begin{array}{l}\text { Raffaella } \\
\text { Clerici, MD }\end{array}$ & $\begin{array}{l}\text { Ospedale Generale di zona } \\
\text { Valduce, Centro ad Alta } \\
\text { Specializzazione per la } \\
\text { diagnosi e la cura della } \\
\text { sclerosi multipla, Como, Italy }\end{array}$ & $\begin{array}{l}\text { Site } \\
\text { investigator }\end{array}$ & $\begin{array}{l}\text { Acquisition of } \\
\text { data }\end{array}$ \\
& & \\
\end{tabular}

\begin{tabular}{|c|c|c|c|}
\hline $\begin{array}{l}\text { Maria Teresa } \\
\text { Ferrò, MD }\end{array}$ & $\begin{array}{l}\text { Ospedale Maggiore di Crema, } \\
\text { Neuroimmunologia - Centro } \\
\text { Provinciale per la diagnosi e } \\
\text { terapia della Sclerosi Multipla, } \\
\text { Crema, Italy }\end{array}$ & $\begin{array}{l}\text { Site } \\
\text { investigator }\end{array}$ & $\begin{array}{l}\text { Acquisition of } \\
\text { data }\end{array}$ \\
\hline $\begin{array}{l}\text { Davide } \\
\text { Maimone, MD }\end{array}$ & $\begin{array}{l}\text { Ospedale Garibaldi, Centro } \\
\text { Sclerosi Multipla, Nesima, Italy }\end{array}$ & $\begin{array}{l}\text { Site } \\
\text { investigator }\end{array}$ & $\begin{array}{l}\text { Acquisition of } \\
\text { data }\end{array}$ \\
\hline $\begin{array}{l}\text { Paola } \\
\text { Valentino, MD }\end{array}$ & $\begin{array}{l}\text { Policlinico Universitario- } \\
\text { Campus Germaneto, Centro } \\
\text { Sclerosi Multipla, Catanzaro, } \\
\text { Italy }\end{array}$ & $\begin{array}{l}\text { Site } \\
\text { investigator }\end{array}$ & $\begin{array}{l}\text { Acquisition of } \\
\text { data }\end{array}$ \\
\hline $\begin{array}{l}\text { Carlo Avolio, } \\
\text { MD }\end{array}$ & $\begin{array}{l}\text { Centro Interdipartimentale } \\
\text { Malattie Demielinizzanti - } \\
\text { AOU Ospedali Riuniti Di } \\
\text { Foggia, Italy }\end{array}$ & $\begin{array}{l}\text { Site } \\
\text { investigator }\end{array}$ & $\begin{array}{l}\text { Acquisition of } \\
\text { data }\end{array}$ \\
\hline $\begin{array}{l}\text { Paola } \\
\text { Crociani, MD }\end{array}$ & $\begin{array}{l}\text { IRCCS Casa Sollievo Della } \\
\text { Sofferenza, Centro SM, SC } \\
\text { Neurologia, S. Giovanni } \\
\text { Rotondo, Italy }\end{array}$ & $\begin{array}{l}\text { Site } \\
\text { investigator }\end{array}$ & $\begin{array}{l}\text { Acquisition of } \\
\text { data }\end{array}$ \\
\hline $\begin{array}{l}\text { Matilde } \\
\text { Inglese, MD }\end{array}$ & $\begin{array}{l}\text { Ospedale Policlinico San } \\
\text { Martino (DiNOGMI), Centro } \\
\text { Per Lo Studio E La Cura Della } \\
\text { Sclerosi Multipla E Malattie } \\
\text { Demielinizzanti - Dipartimento } \\
\text { Di Neuroscienze, } \\
\text { Riabilitazione, Oftalmologia, } \\
\text { Genetica E Scienze } \\
\text { Maternolnfantili, Clinica } \\
\text { Neurologica, Genova, Italy }\end{array}$ & $\begin{array}{l}\text { Site } \\
\text { investigator }\end{array}$ & $\begin{array}{l}\text { Acquisition of } \\
\text { data }\end{array}$ \\
\hline
\end{tabular}

Paola SC Neurologia, Ospedale P. Site Acquisition of

Gazzola, MD Antero Micone, Ambulatorio investigator data Sclerosi Multipla -

Neurologia ASL 4

Chiavarese, Genova, Italy

\begin{tabular}{|c|c|c|c|}
\hline $\begin{array}{l}\text { Roberto } \\
\text { Balgera, MD }\end{array}$ & $\begin{array}{l}\text { MD, Azienda Ospedaliera A. } \\
\text { Manzoni, Centro Sclerosi } \\
\text { Multipla, Divisione di } \\
\text { Neurologia, Lecco, Italy }\end{array}$ & $\begin{array}{l}\text { Site } \\
\text { investigator }\end{array}$ & $\begin{array}{l}\text { Acquisition of } \\
\text { data }\end{array}$ \\
\hline $\begin{array}{l}\text { Marco } \\
\text { Rovaris, MD }\end{array}$ & $\begin{array}{l}\text { IRCCS Fondazione Don Carlo } \\
\text { Gnocchi, Centro SM, Italy }\end{array}$ & $\begin{array}{l}\text { Site } \\
\text { investigator }\end{array}$ & $\begin{array}{l}\text { Acquisition of } \\
\text { data }\end{array}$ \\
\hline $\begin{array}{l}\text { Elio Scarpini, } \\
\text { MD }\end{array}$ & $\begin{array}{l}\text { Ospedale Policlinico, } \\
\text { Università Di Milano, Centro } \\
\text { SM, U.O. Mal. } \\
\text { Neurodegenerative E } \\
\text { Demielinizzanti, Milano, Italy }\end{array}$ & $\begin{array}{l}\text { Site } \\
\text { investigator }\end{array}$ & $\begin{array}{l}\text { Acquisition of } \\
\text { data }\end{array}$ \\
\hline $\begin{array}{l}\text { Alessandra } \\
\text { Protti, MD }\end{array}$ & $\begin{array}{l}\text { ASST Grande Ospedale } \\
\text { Metropolitano Niguarda, } \\
\text { Milano, Italy }\end{array}$ & $\begin{array}{l}\text { Site } \\
\text { investigator }\end{array}$ & $\begin{array}{l}\text { Acquisition of } \\
\text { data }\end{array}$ \\
\hline $\begin{array}{l}\text { Cristoforo } \\
\text { Comi, MD }\end{array}$ & $\begin{array}{l}\text { AOU Maggiore della Carità, } \\
\text { Centro Sclerosi Multipla, } \\
\text { Clinica Neurologica, } \\
\text { Università Piemonte } \\
\text { Orientale, Novara, Italy }\end{array}$ & $\begin{array}{l}\text { Site } \\
\text { investigator }\end{array}$ & $\begin{array}{l}\text { Acquisition of } \\
\text { data }\end{array}$ \\
\hline $\begin{array}{l}\text { Salvatore } \\
\text { Cottone, MD }\end{array}$ & $\begin{array}{l}\text { Centro Di Riferimento } \\
\text { Regionale Per La Malattie } \\
\text { Neuroimmunologiche } \\
\text { Dell'A.O.O.R. Villa Sofia- } \\
\text { Cervello, Palermo, Italy }\end{array}$ & $\begin{array}{l}\text { Site } \\
\text { investigator }\end{array}$ & $\begin{array}{l}\text { Acquisition of } \\
\text { data }\end{array}$ \\
\hline
\end{tabular}


Appendix 2 (continued)

\begin{tabular}{|c|c|c|c|}
\hline Name & Location & Role & Contribution \\
\hline $\begin{array}{l}\text { Francesco } \\
\text { Corea, MD }\end{array}$ & $\begin{array}{l}\text { Ospedale San Giovanni } \\
\text { Battista, Ambulatorio } \\
\text { malattie infiammatorie } \\
\text { demielinizzanti, Foligno, } \\
\text { Italy }\end{array}$ & $\begin{array}{l}\text { Site } \\
\text { investigator }\end{array}$ & $\begin{array}{l}\text { Acquisition of } \\
\text { data }\end{array}$ \\
\hline $\begin{array}{l}\text { Roberto } \\
\text { Bergamaschi, } \\
\text { MD }\end{array}$ & $\begin{array}{l}\text { S.S. Sclerosi Multipla } \\
\text { dell'IRCCS Fondazione } \\
\text { Istituto Neurologico } \\
\text { Nazionale C. Mondino, } \\
\text { Pavia, Italy }\end{array}$ & $\begin{array}{l}\text { Site } \\
\text { investigator }\end{array}$ & $\begin{array}{l}\text { Acquisition of } \\
\text { data }\end{array}$ \\
\hline $\begin{array}{l}\text { Umberto } \\
\text { Aguglia, MD }\end{array}$ & $\begin{array}{l}\text { Grande Ospedale } \\
\text { Metropolitano Bianchi } \\
\text { Melacrino Morelli, } \\
\text { Ambulatorio Sclerosi } \\
\text { Multipla, Reggio Calabria, } \\
\text { Italy }\end{array}$ & $\begin{array}{l}\text { Site } \\
\text { investigator }\end{array}$ & $\begin{array}{l}\text { Acquisition of } \\
\text { data }\end{array}$ \\
\hline $\begin{array}{l}\text { Marco } \\
\text { Salvetti, MD }\end{array}$ & $\begin{array}{l}\text { CENTERS Centro } \\
\text { Neurologico Terapie } \\
\text { Sperimentali, Sapienza } \\
\text { Università Di Roma, Azienda } \\
\text { Ospedaliera S. Andrea, } \\
\text { Roma, Italy }\end{array}$ & $\begin{array}{l}\text { Site } \\
\text { investigator }\end{array}$ & $\begin{array}{l}\text { Acquisition of } \\
\text { data }\end{array}$ \\
\hline $\begin{array}{l}\text { Carlo Pozzilli, } \\
\text { MD }\end{array}$ & $\begin{array}{l}\text { Policlinico S. Andrea, Centro } \\
\text { SM, Università Sapienza } \\
\text { Roma, Italy }\end{array}$ & $\begin{array}{l}\text { Site } \\
\text { investigator }\end{array}$ & $\begin{array}{l}\text { Acquisition of } \\
\text { data }\end{array}$ \\
\hline $\begin{array}{l}\text { Antonella } \\
\text { Conte, MD }\end{array}$ & $\begin{array}{l}\text { Policlinico Umberto I, } \\
\text { Università Sapienza Roma, } \\
\text { Italy }\end{array}$ & $\begin{array}{l}\text { Site } \\
\text { investigator }\end{array}$ & $\begin{array}{l}\text { Acquisition of } \\
\text { data }\end{array}$ \\
\hline $\begin{array}{l}\text { Girolama } \\
\text { Marfia, MD }\end{array}$ & $\begin{array}{l}\text { Policlinico Università di } \\
\text { Roma Tor Vergata, UOSB } \\
\text { Centro di Riferimento } \\
\text { Regionale per la Sclerosi } \\
\text { Multipla, Roma, Italy }\end{array}$ & $\begin{array}{l}\text { Site } \\
\text { investigator }\end{array}$ & $\begin{array}{l}\text { Acquisition of } \\
\text { data }\end{array}$ \\
\hline $\begin{array}{l}\text { Giuseppe } \\
\text { Santuccio, } \\
\text { MD }\end{array}$ & $\begin{array}{l}\text { Azienza Socio Sanitaria } \\
\text { Territoriale (ASST) della } \\
\text { Valtellina e Alto Lario, } \\
\text { reparto di Neurologia, Sedi } \\
\text { di Sondrio e Sondalo, Italy }\end{array}$ & $\begin{array}{l}\text { Site } \\
\text { investigator }\end{array}$ & $\begin{array}{l}\text { Acquisition of } \\
\text { data }\end{array}$ \\
\hline $\begin{array}{l}\text { Mauro } \\
\text { Zaffaroni, MD }\end{array}$ & $\begin{array}{l}\text { Ospedale Di Gallarate, } \\
\text { Centro Sclerosi Multipla, } \\
\text { ASST Della Valle Olona, } \\
\text { Gallarate, Italy }\end{array}$ & $\begin{array}{l}\text { Site } \\
\text { investigator }\end{array}$ & $\begin{array}{l}\text { Acquisition of } \\
\text { data }\end{array}$ \\
\hline $\begin{array}{l}\text { Davide } \\
\text { Nasuelli, MD }\end{array}$ & $\begin{array}{l}\text { Presidio Ospedaliero Di } \\
\text { Saronno ASST Della Valle } \\
\text { Olona Ambulatorio Sclerosi } \\
\text { Multipla, Saronno, Italy }\end{array}$ & $\begin{array}{l}\text { Site } \\
\text { investigator }\end{array}$ & $\begin{array}{l}\text { Acquisition of } \\
\text { data }\end{array}$ \\
\hline $\begin{array}{l}\text { Paola Banfi, } \\
\text { MD }\end{array}$ & $\begin{array}{l}\text { Ospedale di Circolo e } \\
\text { Fondazione Macchi, Centro } \\
\text { Sclerosi Multipla, } \\
\text { Ambulatorio Malattie } \\
\text { Demielinizzanti, Varese, Italy }\end{array}$ & $\begin{array}{l}\text { Site } \\
\text { investigator }\end{array}$ & $\begin{array}{l}\text { Acquisition of } \\
\text { data }\end{array}$ \\
\hline
\end{tabular}

\section{References}

1. Zhou P, Yang XL, Wang XG, et al. A pneumonia outbreak associated with a new coronavirus of probable bat origin. Nature. 2020;579(7798):270-273.
2. Mares J, Hartung HP. Multiple sclerosis and COVID-19. Biomed Pap Med Fac Univ Palacky Olomouc Czech Repub. 2020;164(3):217-225.

3. Winkelmann A, Loebermann M, Reisinger EC, et al. Disease modifying therapies and infectious risks in multiple sclerosis. Nat Rev Neurol. 2016;12(4):217-233.

4. Sormani MP, De Rossi N, Schiavetti I, et al. Disease-modifying therapies and coronavirus disease 2019 severity in multiple sclerosis. Ann Neurol. 2021;89(4):780-789.

5. Louapre C, Collongues N, Stankoff B, et al. Clinical characteristics and outcomes in patients with coronavirus disease 2019 and multiple sclerosis. JAMA Neurol. 2020; 77(9):1079-1088.

6. Salter A, Fox RJ, Newsome SD, et al. Outcomes and risk factors associated with SARSCoV-2 infection in a North American registry of patients with multiple sclerosis. JAMA Neurol. 2021;78(6):699-708.

7. Sormani MP, Salvetti M, Labaige P, et al. DMTs and Covid-19 severity in MS: a pooled analysis from Italy and France. Ann Clin Transl Neurol. 2021;8(8):1738-1744.

8. Arrambide G, Llaneza-González MÁ, Costa-Frossard França L, et al. SARS-CoV-2 infection in multiple sclerosis: results of the Spanish Neurology Society Registry. Neurol Neuroimmunol Neuroinflamm. 2021;8(5):e1024.

9. Moreno-Torres I, Meca Lallana V, Costa-Frossard L, et al. Risk and outcomes of Covid-19 in patients with multiple sclerosis. Eur J Neurol. 2021;28(11):3712-3721.

10. Giovannoni G, Hawkes C, Lechner-Scott J, et al. The Covid-19 pandemic and the use of MS disease modifying therapies. Mult Scler Relat Disord. 2020;39:102073.

11. Prosperini L, Kinkel RP, Miravalle AA, et al. Post-natalizumab disease reactivation in multiple sclerosis: systematic review and meta-analysis. Ther Adv Neurol Disord. 2019; 12:1756286419837809.

12. Pantazou V, Pot C, Du Pasquier R, et al. Recurrence of disease activity after fingolimod discontinuation in older patients previously stable on treatment. Mult Scler Relat Disord. 2021;51:102918.

13. Wiendl H, Carraro M, Comi G, et al. Lymphocyte pharmacodynamics are not associated with autoimmunity or efficacy after alemtuzumab. Neurol Neuroimmunol Neuroinflamm. 2019;7(1):e635.

14. Pardo G, Jones DE. The sequence of disease-modifying therapies in relapsing multiple sclerosis: safety and immunologic considerations. J Neurol. 2017;264(12):2351-2374.

15. Trojano M, Bergamaschi R, Amato MP, et al. The Italian multiple sclerosis register. Neurol Sci. 2019;40(1):155-165.

16. meddra.org.

17. Yanovitzky I, Zanutto E, Hornik R. Estimating causal effects of public health education campaigns using propensity score methodology. Eval Program Plann. 2005;28(2): 209-220.

18. Parsons LS. Reducing bias in a propensity score matched pair sample using greedy matching techniques. In: Proceedings of the Twenty-Sixth Annual SAS Users Group International Conference. SAS Institute; 2004.

19. Austin PC, Grootendorst P, Anderson GM. A comparison of the ability of different propensity score models to balance measured variables between treated and untreated subjects: a Monte Carlo study. Stat Med. 2007;26(4):734-753.

20. Chaudhry F, Jageka C, Levy PD, et al. Review of the COVID-19 risk in multiple sclerosis. J Cell Immunol. 2021;3(2):68-77.

21. Liu JY, Dickter JK. Nosocomial infections: a history of hospital-acquired infections. Gastrointest Endosc Clin N Am. 2020;30(4):637-652.

22. Borro L, Mazzei L, Raponi M, et al. The role of air conditioning in the diffusion of Sars-CoV-2 in indoor environments: a first computational fluid dynamic model, based on investigations performed at the Vatican State Children's Hospital. Environ Res. 2021;193:110343.

23. Reyes $\mathrm{S}$, Cunningham AL, Kalincik $\mathrm{T}$, et al. Update on the management of multiple sclerosis during the COVID-19 pandemic and post pandemic: an international consensus statement. J Neuroimmunol. 2021;357:577627.

24. Nottingham University Hospitals NHS Trust, UK. COVID-19 Risk From Attending Outpatient Radiology Appointments. Accessed August 10, 2021. clinialtrials.gov/ct2/ show/NCT04544176.

25. Reder AT, Centonze D, Naylor ML, et al. COVID-19 in patients with multiple sclerosis: associations with disease-modifying therapies. CNS Drugs. 2021;35(3): 317-330.

26. Hill-Cawthorne GA, Button T, Tuohy O, et al. Long-term lymphocyte reconstitution after alemtuzumab treatment of multiple sclerosis. J Neurol Neurosurg Psychiatry. 2012;83(3):298-304.

27. Durelli L, De Mercanti S, Rolla S, et al. Alemtuzumab long-term immunological study: the immunosuppressive effect does not last more than 48 months. Neurology. 2016; 86(S2):008.

28. Ocrevus Prescribing Information. Genentech Inc.; 2017.

29. Plavina T, Fox EJ, Lucas N, et al. A randomized trial evaluating various administration routes of natalizumab in multiple sclerosis. J Clin Pharmacol. 2016;56(10):1254-1262.

30. Trojano M, Ramió-Torrentà L, Grimaldi LM, et al. A randomized study of natalizumab dosing regimens for relapsing-remitting multiple sclerosis. Mult Scler. 2021; 27(14):2240-2253. 


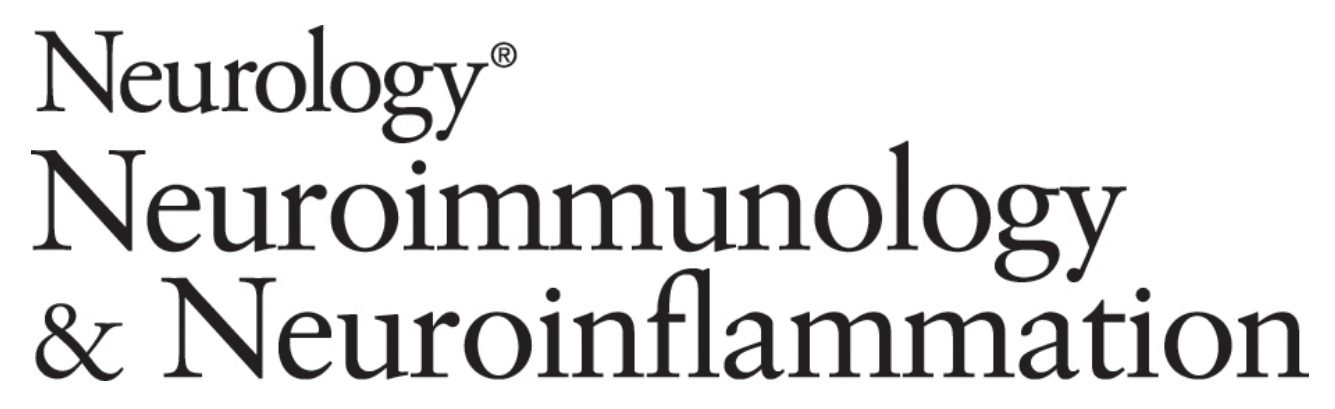

Risk of Getting COVID-19 in People With Multiple Sclerosis: A Case-Control Study Pietro Iaffaldano, Giuseppe Lucisano, Alessia Manni, et al.

Neurol Neuroimmunol Neuroinflamm 2022;9;

DOI 10.1212/NXI.0000000000001141

This information is current as of January 19, 2022

Neurol Neuroimmunol Neuroinflamm is an official journal of the American Academy of Neurology.

Published since April 2014, it is an open-access, online-only, continuous publication journal. Copyright

Copyright $\odot 2022$ The Author(s). Published by Wolters Kluwer Health, Inc. on behalf of the American

Academy of Neurology.. All rights reserved. Online ISSN: 2332-7812.

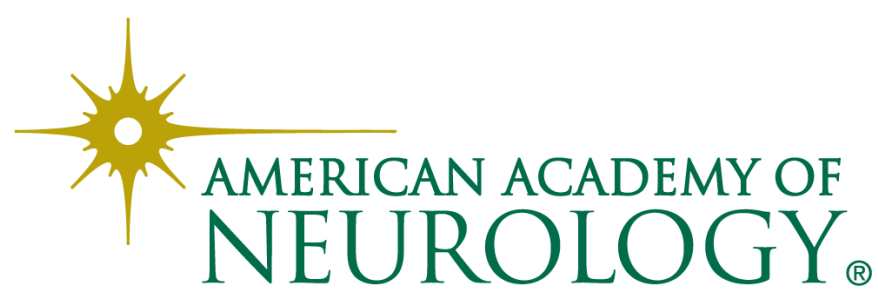




\section{Updated Information \& Services}

References

Citations

Subspecialty Collections

Permissions \& Licensing

Reprints including high resolution figures, can be found at: http://nn.neurology.org/content/9/2/e1141.full.html

This article cites 26 articles, 3 of which you can access for free at: http://nn.neurology.org/content/9/2/e1141.full.html\#\#ref-list-1

This article has been cited by 3 HighWire-hosted articles: http://nn.neurology.org/content/9/2/e1141.full.html\#\#otherarticles

This article, along with others on similar topics, appears in the following collection(s):

\section{Case control studies}

http://nn.neurology.org//cgi/collection/case_control_studies Class III

http://nn.neurology.org//cgi/collection/class_iii

\section{COVID-19}

http://nn.neurology.org//cgi/collection/covid_19

Multiple sclerosis

http://nn.neurology.org//cgi/collection/multiple_sclerosis

Information about reproducing this article in parts (figures,tables) or in its entirety can be found online at:

http://nn.neurology.org/misc/about.xhtml\#permissions

Information about ordering reprints can be found online: http://nn.neurology.org/misc/addir.xhtml\#reprintsus

Neurol Neuroimmunol Neuroinflamm is an official journal of the American Academy of Neurology.

Published since April 2014, it is an open-access, online-only, continuous publication journal. Copyright

Copyright $\odot 2022$ The Author(s). Published by Wolters Kluwer Health, Inc. on behalf of the American Academy of Neurology.. All rights reserved. Online ISSN: 2332-7812.

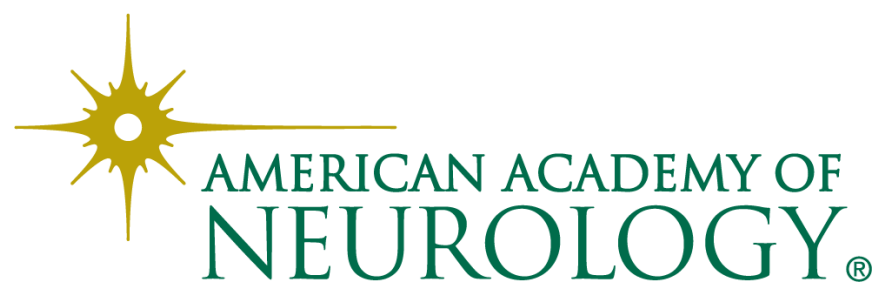

